\title{
Pesticide residues analysis in water samples of Nagarpur and Saturia Upazila, Bangladesh
}

\author{
M. Hasanuzzaman' ${ }^{1}$ M. A. Rahman ${ }^{2} \cdot$ M. S. Islam² $\cdot$ M. A. Salam² $\cdot$ M. R. Nabi $^{2}$
}

Received: 9 September 2015 / Accepted: 20 December 2017 / Published online: 24 January 2018

(c) The Author(s) 2018. This article is an open access publication

\begin{abstract}
Pesticides used to protect the crops from pest attack in the agricultural fields pose harmful effect to the non-target organisms such as human and many other aquatic and terrestrial organisms either directly or indirectly through food chain. The present study was conducted to monitor a total of seven pesticide residues under organochlorine, organophosphorus and carbamate pesticides in three different sources of pond water, paddy field water and tube-well water from Nagarpur Upazila and paddy field water in the company of Dhaleshwari and Gazikhali river water from Saturia Upazila, Bangladesh. A total of 40 water samples were analyzed using high-performance liquid chromatography equipped with ultraviolet detector. Among the organophosphorus pesticides, diazinon was detected in eight water samples at a concentration ranging from 4.11 to $257.91 \mu \mathrm{g} / \mathrm{l}$ whereas, malathion was detected only in one water sample at a concentration of $84.64 \mu \mathrm{g} / \mathrm{l}$ and chlorpyrifos pesticide was also detected only in one water sample and the concentration was $37.3 \mu \mathrm{g} / \mathrm{l}$. Trace amount of carbaryl was identified but it was below the detection limit. None of the tested water samples was found to be contaminated with DDT or its metabolites (DDE and DDD). The water samples contaminated with the suspected pesticides were above the acceptable limit except for the fish pond samples of Sahabatpur and Dubaria union. To control the misuse of pesticides and to reduce the possible health risk, appropriate control systems of pests such as integrated pest management system should be implemented immediately by the authorities of the country.
\end{abstract}

Keywords Pesticide $\cdot$ Water sample $\cdot$ HPLC $\cdot$ Organochlorine $\cdot$ Organophosphorus $\cdot$ IPM

\section{Introduction}

Bangladesh is an agricultural country. About $18.70 \%$ of the total GDP of Bangladesh is contributed by agriculture (BBS 2013). About $80 \%$ of the people depend on agriculture for their livelihood (Chowdhury et al. 2011). The GDP in agriculture is 3.04\% in FY 2014-15 with great contribution of $22.60 \%$ in total agricultural income by Fisheries alone (MoF 2015).

M. Hasanuzzaman

mhasanuzzaman72@yahoo.com

1 Agrochemical and Environmental Research Division, Institute of Food and Radiation Biology (IFRB), Atomic Energy Research Establishment (AERE), Bangladesh Atomic Energy Commission, Ganakbari, Savar, GPO Box 3787, Dhaka 1000, Bangladesh

2 Department of Zoology, Jahangirnagar University, Savar, Dhaka 1342, Bangladesh
Globally, there are an estimation of 70,000 different pest species together with insects and mites, plant pathogens and weeds which causes an estimation of 14, 13 and 13\% agricultural crop damage, respectively (Pimentel 2009a). In Bangladesh, about $40 \%$ of the crop loss is caused by pests and insects attack which is a considerable loss (Bagchi et al. 2009). Crop loss from pests can be reduced to $35-42 \%$ using pesticides (Pimentel 1997) although risks of using pesticides are serious as well (Pimentel 2009b). Because of inadequate knowledge and instruction about the application of pesticide, farmers spray excessive amount of organophosphate and carbamate pesticides in the cultivated lands (Bhattacharjee et al. 2012).

The surface and ground water bodies are easily being contaminated by runoff water or by rain for the indiscriminate use of pesticide. According to Rahman (2000), the widespread use of pesticide may contaminate the environment and freshwater fish. It is obligatory of entering the fractions of applied insecticides into the aquatic ecosystems due to the 
application techniques for crop protection (Van Wijngaarden et al. 2005).

From water bodies, pesticide residues directly or indirectly pass through the food chain and eventually cause harm to human and other aquatic or terrestrial organisms. Several problems can be caused in human body due to pesticide exposure. Organophosphorous pesticides (OP) may affect sperm chromosome segregation and augment the risk for genetic syndromes (Recio et al. 2001). Lee et al. (2004) reported an association between chlorpyrifos use and incidence of lung cancer in Iowa and North Carolina. Pahwa et al. (2011) observed the association of soft-tissue sarcoma with specific pesticides such as aldrin and diazinon in six regions of Canada. Organochlorine (OC) pesticide use is related with an increase in cancer risk (Xu et al. 2010). A positive association of pesticide exposure with Parkinson's disease (PD) was shown by Hancock et al. (2008).

In Bangladesh, endrin was the first imported pesticide of which 3 metric tons (MT) were imported in 1955 for agricultural pest control (Rahman 2004). Primarily, the government of Bangladesh provided a 100\% financial assistance for pesticides and were supplied free of cost to the farmers but the pesticide industry was privatized in 1979 when $100 \%$ price was imposed (GoB, MoEF 2005).

Presently, there are a total of 141 active ingredients represented by 425 trade names, registered as public health pesticides (PHP) and agricultural pesticides (AP) in Bangladesh (GoB, MoEF 2005). Out of the total pesticides use, over 80 pesticides are used in rice fields alone (Ara et al. 2014). On the other hand, the consumption of pesticides in Bangladesh increased from 11,610.66 to 40,882.94 MT from the year 1998-2012 (BBS 2013).

Pesticides through food chain can be stored in the human body and may cause several health hazards because of prolonged consumption. The present study was conducted to reveal the original scenario of pesticide application by the farmers and to assess the possible health risk through identification and quantification of the pesticide residues in water samples in these regions.

\section{Materials and methods}

The present study was conducted for monitoring of pesticide residues in three different sources of pond water, paddy field water and tube-well water from ten unions of Nagarpur Upazila under Tangail district and paddy field water in the company of Dhaleshwari and Gazikhali river water from nine unions of Saturia Upazila under Manikganj district, Bangladesh.

To carry out the present study, a total of 30 water samples from Nagarpur Upazila and ten water samples from Saturia Upazila were collected in plastic bottle having $500 \mathrm{ml}$ for each sample and were labeled as well as instantly carried to the laboratory and kept at $-20{ }^{\circ} \mathrm{C}$ for further analysis. For determination of pesticide residues, $250 \mathrm{ml}$ of water sample and $100 \mathrm{ml}$ of double-distilled (DD) $n$-hexane (Merck, Germany) as solvent was taken into a $1000-\mathrm{ml}$ separating funnel and shaken by mixing well for about 10 min and then kept standing for $10 \mathrm{~min}$ for settling down. Then, lower aqueous layer and upper hexane layer were collected in separate conical flasks. The aqueous layer was re-extracted twice by adding $50 \mathrm{ml}$ solvent (DD $n$-hexane) for each re-extraction and then the solvent layer (upper) was collected. Combined extract was collected with anhydrous sodium sulfate $\left(\mathrm{Na}_{2} \mathrm{SO}_{4}\right)$ (Merck, Germany) for removing water (if any). The collected extract was then concentrated using a rotary vacuum evaporator (R-215, Buchi, Switzerland). The concentrated extract was then transferred to a vial ringing the round bottom flask for three times with DD $n$-hexane with a volume of 3,2 and $2 \mathrm{ml}$, respectively, and making the volume of $7 \mathrm{ml}$.

Cleanup of the extract was done over florisil (magnesium silicate, mesh 60-100, active at $1250^{\circ} \mathrm{F}$, Janssen Chimica) packed with anhydrous sodium sulfate at the top of the column. The extract was eluted with $100 \mathrm{ml} \mathrm{DD} n$-hexane in the company of $2 \%$ diethyl ether (BDH, England) (doubledistilled) in a flow rate of $5 \mathrm{ml} / \mathrm{min}$. Again the extract was evaporated at $40^{\circ} \mathrm{C}$ by vacuum rotary evaporator and transfer into vials. The extracts were then evaporated by nitrogen gas using $\mathrm{N}_{2}$ blower (PU 90003, Alfa industry, England) and dried completely. Final volume was made adding $1 \mathrm{ml}$ of HPLC-grade acetonitrile (Merck, Germany) prior to injection.

For pesticide residues analysis, aliquot $(20 \mu \mathrm{l})$ was injected by microliter syringe into the high-performance liquid chromatography (Waters Company, England) fitted with ultraviolet (UV) detector. The mobile phase was a combination of $65 \%$ acetonitrile and $35 \%$ distilled water. Column $\mathrm{C}_{18}$ (Nova Pack) along with the output device at $254 \mathrm{~nm}$ absorbance was used for determination of the level of organochlorine (DDT, DDE and DDD), organophosphorus (malathion, diazinon and chlorpyrifos) and carbamate (carbaryl) pesticides.

Identification of the suspected pesticide residues were done in relation with retention time (RT) of pure analytical standards which were purchased from GmbH (D-86199 Augsburg, Germany). The quantity was measured with formation of calibration curve from standard samples of different concentrations. The calibration curves for organochlorine, organophosphorus and carbamate pesticides were prepared at three different concentrations of 5,10 and $20 \mu \mathrm{g} / \mathrm{l}$ of the standard solutions. The mean percentage recoveries with standard deviation $( \pm \mathrm{SD})$ of DDT, DDE, DDD, malathion, diazinon, chlorpyrifos and carbaryl in the spiked positive controls of the water samples with the 
florisil cleanup system were $90.13 \pm 1.36,80.07 \pm 0.61$, $86.28 \pm 0.53,89.33 \pm 3.29,82.57 \pm 2.21,83.84 \pm 1.43$, and $89.48 \pm 1.65 \%$, respectively, which is shown in Table 1 .

The mean percentage recoveries for the various pesticides were calculated using the following equation:

$P_{i}=\left(S_{i} / T_{i}\right) \times 100$

where $P_{i}$ is the percent recovery, $S_{i}$ is the analytical results from the laboratory control standard and $T_{i}$ is the known concentration of the spike. Recovery test has been done three times for each pesticide and the mean value of recovery test for each pesticide has been calculated. Statistical analysis was done using SPSS (Version 11.5).

\section{Results and discussion}

A total of forty water samples from Nagarpur and Saturia Upazila were collected to identify and quantify the presence of organochlorine, organophosphorus and carbamate pesticides. The results of the tested water samples contaminated with suspected pesticide residues are shown in Table 2.

Among organophosphorus pesticides, diazinon was detected in eight water samples at a concentration ranging from 4.11 to $257.91 \mu \mathrm{g} / \mathrm{l}$ which are above the Canadian maximum acceptable concentration (MAC) of $20 \mu \mathrm{g} / 1$ except for the results of water samples from Sahabatpur and Dubaria union (water sample no. 14 and 26, respectively) for diazinon (Health Canada 2014). The result is also above the European guideline value of $0.1 \mu \mathrm{g} / \mathrm{l}$ for individual pesticides (EU 1998). The detected mean concentration with standard deviation (mean \pm SD) of diazinon was $16.58 \pm 49.13 \mu \mathrm{g} / 1$ (Table 2). Previously, diazinon was detected by Uddin et al. (2013) in Meherpur region at a concentration ranging from 32.8 to $79 \mu \mathrm{g} / \mathrm{l}$. Hasanuzzaman et al. (2017) reported the presence of diazinon at the concentration of $31.497 \mu \mathrm{g} / \mathrm{l}$ in a water sample of Dhamrai Upazila, Bangladesh. Chowdhury et al. (2012a) also reported the presence of diazinon at the concentration of $0.9 \mu \mathrm{g} / \mathrm{l}$ in Savar. Diazinon was reported at the concentration of $7.86 \mu \mathrm{g} / \mathrm{l}$ in the lake of Savar (Hossain et al. 2014) and at the concentration of $0.027 \mu \mathrm{g} / \mathrm{l}$ in the paddy field of Manikganj (Bhattacharjee et al. 2012). Brigham (1994) found diazinon from less than $0.004-0.008 \mu \mathrm{g} / \mathrm{l}$ in stream-water samples of USA.

During the study period, malathion was detected only in one water sample at a concentration of $84.64 \mu \mathrm{g} / 1$ with mean $( \pm \mathrm{SD})$ concentration of $2.12 \pm 13.38 \mu \mathrm{g} / \mathrm{l}$ and the result is higher than the Australian health-based guideline value of $70 \mu \mathrm{g} / \mathrm{l}$ for malathion (NHMRC, NRMMC 2011). The concentration is also above the European guideline
Table 1 Results of recovery experiment

\begin{tabular}{|c|c|c|c|c|c|c|c|}
\hline Pesticide & Spiked $(\mu \mathrm{g})$ & $\begin{array}{l}\text { Measured } \\
\text { value }(\mu \mathrm{g})\end{array}$ & $\begin{array}{l}\text { Mean meas- } \\
\text { ured value } \\
(\mu \mathrm{g})\end{array}$ & SD & Recoveries (\%) & $\begin{array}{l}\text { Mean } \\
\text { recoveries } \\
(\%)\end{array}$ & SD \\
\hline \multirow[t]{3}{*}{ DDT } & 200 & 177.15 & \multirow[t]{3}{*}{180.25} & \multirow[t]{3}{*}{ \pm 2.73} & 88.58 & \multirow[t]{3}{*}{90.13} & \multirow[t]{3}{*}{ \pm 1.36} \\
\hline & 200 & 181.32 & & & 90.66 & & \\
\hline & 200 & 182.28 & & & 91.14 & & \\
\hline \multirow[t]{3}{*}{ DDE } & 200 & 160.5 & \multirow[t]{3}{*}{160.13} & \multirow[t]{3}{*}{ \pm 1.21} & 80.25 & \multirow[t]{3}{*}{80.07} & \multirow[t]{3}{*}{ \pm 0.61} \\
\hline & 200 & 161.12 & & & 80.56 & & \\
\hline & 200 & 158.77 & & & 79.39 & & \\
\hline \multirow[t]{3}{*}{ DDD } & 200 & 171.5 & \multirow[t]{3}{*}{172.56} & \multirow[t]{3}{*}{ \pm 1.06} & 85.75 & \multirow[t]{3}{*}{86.28} & \multirow[t]{3}{*}{ \pm 0.53} \\
\hline & 200 & 173.61 & & & 86.81 & & \\
\hline & 200 & 172.57 & & & 86.29 & & \\
\hline \multirow[t]{3}{*}{ Malathion } & 200 & 184.11 & \multirow[t]{3}{*}{178.65} & \multirow[t]{3}{*}{ \pm 6.59} & 92.06 & \multirow[t]{3}{*}{89.33} & \multirow[t]{3}{*}{ \pm 3.29} \\
\hline & 200 & 180.51 & & & 90.26 & & \\
\hline & 200 & 171.33 & & & 85.67 & & \\
\hline \multirow[t]{3}{*}{ Diazinon } & 200 & 160.15 & \multirow[t]{3}{*}{165.13} & \multirow[t]{3}{*}{ \pm 4.42} & 80.08 & \multirow[t]{3}{*}{82.57} & \multirow[t]{3}{*}{ \pm 2.21} \\
\hline & 200 & 168.61 & & & 84.31 & & \\
\hline & 200 & 166.63 & & & 83.32 & & \\
\hline \multirow[t]{3}{*}{ Chlorpyrifos } & 200 & 168.21 & \multirow[t]{3}{*}{167.67} & \multirow[t]{3}{*}{ \pm 2.86} & 84.11 & \multirow[t]{3}{*}{83.84} & \multirow[t]{3}{*}{ \pm 1.43} \\
\hline & 200 & 164.58 & & & 82.29 & & \\
\hline & 200 & 170.22 & & & 85.11 & & \\
\hline \multirow[t]{3}{*}{ Carbaryl } & 200 & 175.28 & \multirow[t]{3}{*}{178.96} & \multirow[t]{3}{*}{ \pm 3.31} & 87.64 & \multirow[t]{3}{*}{89.48} & \pm 1.65 \\
\hline & 200 & 179.92 & & & 89.96 & & \\
\hline & 200 & 181.68 & & & 90.84 & & \\
\hline
\end{tabular}

$S D$ standard deviation 
Table 2 Results of the suspected pesticide residues detected in the water samples

\begin{tabular}{|c|c|c|c|c|c|c|c|c|}
\hline Water sample no. & Location & Diazinon $(\mu \mathrm{g} / \mathrm{l})$ & Malathion $(\mu \mathrm{g} / \mathrm{l})$ & $\begin{array}{l}\text { Chlor- } \\
\text { pyrifos } \\
(\mu \mathrm{g} / \mathrm{l})\end{array}$ & Carbaryl $(\mu \mathrm{g} / \mathrm{l})$ & DDT $(\mu \mathrm{g} / 1)$ & $\operatorname{DDE}(\mu \mathrm{g} / \mathrm{l})$ & $\operatorname{DDD}(\mu \mathrm{g} / \mathrm{l})$ \\
\hline 2 & Nagarpur (M), FP & 257.91 & BDL & BDL & BDL & BDL & BDL & BDL \\
\hline 3 & Nagarpur (M), PF & 134.95 & BDL & BDL & BDL & BDL & BDL & BDL \\
\hline 6 & Pakutia (U), PF & 74.61 & BDL & BDL & BDL & BDL & $\mathrm{BDL}$ & BDL \\
\hline 8 & Mukna (U), FP & 108.65 & 84.64 & BDL & BDL & BDL & BDL & BDL \\
\hline 9 & Mukna (U), PF & 29.73 & $\mathrm{BDL}$ & BDL & $\mathrm{BDL}$ & BDL & $\mathrm{BDL}$ & $\mathrm{BDL}$ \\
\hline 11 & Bhadra (U), FP & 45.34 & BDL & BDL & BDL & BDL & BDL & BDL \\
\hline 12 & Bhadra (U), PF & $\mathrm{BDL}$ & BDL & 37.3 & BDL & BDL & BDL & BDL \\
\hline 14 & Sahabatpur (U), FP & 8.03 & BDL & BDL & $\mathrm{BDL}$ & BDL & BDL & BDL \\
\hline 26 & Dubaria (U), FP & 4.11 & BDL & BDL & $\mathrm{BDL}$ & BDL & $\mathrm{BDL}$ & BDL \\
\hline \multicolumn{2}{|l|}{ Mean } & 16.58 & 2.12 & 0.93 & 0 & 0 & 0 & 0 \\
\hline \multicolumn{2}{|c|}{ Standard deviation $( \pm \mathrm{SD})$} & 49.13 & 13.38 & 5.9 & 0 & 0 & 0 & 0 \\
\hline
\end{tabular}

$M$ municipality, $U$ union, $F P$ fish pond, $P F$ paddy field, $B D L$ bellow detection limit, below detection limits (BDL) which stand 0 for the calculation of mean and standard deviation, total number of water sample is 40 but only location-wise contamination status has been presented here

value of $0.1 \mu \mathrm{g} / \mathrm{l}$ for individual pesticides (EU 1998). The presence of malathion in seven water samples ranging from 42.58 to $922.8 \mu \mathrm{g} / \mathrm{l}$ in Dhamrai region, Bangladesh was reported by Hasanuzzaman et al. (2017). Chowdhury et al. (2012a) reported the similar result $(105.2 \mu \mathrm{g} / \mathrm{l})$ in a water sample from Dhamrai Upazila. Malathion was also detected by Hossain et al. (2014) at a concentration from 23.1 to $59.9 \mu \mathrm{g} / \mathrm{l}$ in lakes adjacent to agricultural fields of Savar, Bangladesh. Diazinon was reported from 0.24 to $1.8 \mu \mathrm{g} / \mathrm{l}$ in Southern Ontario agricultural watersheds (Braun and Frank 1980) and $0.99 \mu \mathrm{g} / \mathrm{l}$ in Ontario river basins (Frank and Logan 1988).

Among 40 water samples, chlorpyrifos pesticide was detected only in one water sample and the concentration was $37.3 \mu \mathrm{g} / \mathrm{l}$. The mean concentration of chlorpyrifos with standard deviation was $0.93 \pm 5.9 \mu \mathrm{g} / \mathrm{l}$ (Table 2). The result is above the Canadian maximum acceptable concentration (MAC) and WHO acceptable daily intake (ADI) value of $10 \mu \mathrm{g} / \mathrm{l}$ (Health Canada 2014; WHO 2008). The result is also above the desirable limit of Indian standard of $30 \mu \mathrm{g} / \mathrm{l}$ (BIS 2009). Chowdhury et al. (2012b) reported the water samples contaminated with chlorpyrifos ranging from 0.477 to $1.189 \mu \mathrm{g} / \mathrm{l}$ in Rangpur district. Chlorpyrifos was also detected in water samples of Savar Upazila at the concentration from 3.27 to $9.31 \mu \mathrm{g} / \mathrm{l}$ which were within the acceptable range.

Out of 40 water samples, trace amount of carbaryl was identified in several samples but were beyond the detection limit. Chowdhury et al. (2012a) reported carbaryl in the water samples of Dhamrai Upazila from 14.1 to $18.1 \mu \mathrm{g} / \mathrm{l}$. Carbaryl was also detected in the water samples of paddy field ranging from 0.055 to $0.163 \mu \mathrm{g} / \mathrm{l}$ in Rangpur (Chowdhury et al. 2012b) and near of the vegetable fields of Savar Upazila ranging from 4.6 to $6.3 \mu \mathrm{g} / \mathrm{l}$ (Hossain et al. 2014).
Out of seven suspected pesticide residues, only malathion, diazinon and chlorpyrifos residues were detected in 9 water samples out of 40 tested samples. Within the 40 $(100 \%)$ water samples, diazinon residue were detected in 8 or $20 \%$ of water samples, whereas both malathion and chlorpyrifos residues were detected in each for one water sample or $2.5 \%$ (Fig. 1). Malathion and diazinon have been detected in the same water sample (sample no. 8) as a result; the percentage of water sample contaminated with malathion $(2.5 \%)$ is included within that of diazinon (20\%). The residues of DDT, DDE, DDD, and carbaryl were not detected $(0 \%)$ at any of the water samples. On the other hand, a total of 31 or $77.5 \%$ samples remained uncontaminated (Fig. 1).

During the study period organochlorine pesticides (DDT, DDE and DDD) were not detected in any of the water samples from Nagarpur Upazila and Saturia Upazila. This may be due to the banning the use of DDT by the government of

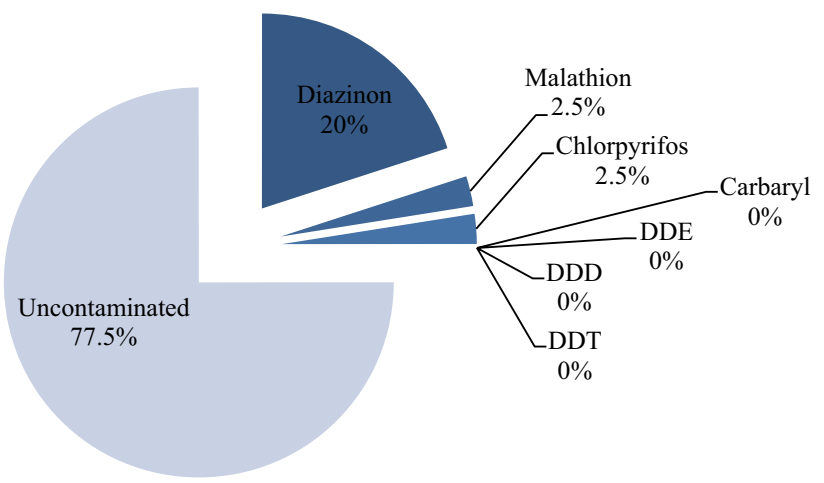

Fig. 1 Contamination status of the water samples Asterisk since, the water sample (sample no. 8) is contaminated with both malathion and diazinon residues; the percentage of water sample contamination by malathion $(2.5 \%)$ is included within that of diazinon $(20 \%)$ 
Bangladesh. Bangladesh banned agricultural use of DDT in the year of 1997 (DoE 2007). Bangladesh signed to the Stockholm Convention on Persistent Organic Pollutants (POPs) held on 23 May 2001 in Stockholm, Sweden (DoE 2007). Protecting the human health and the environment from persistent organic pollutant is the objective of the convention. Case studies revealed the old stocks of some POPs pesticides at different places and continuous use of DDT for controlling mosquito vectors of malaria and dry fish insect in Bangladesh (ESDO 2005), as a result DDT and its metabolites (DDE and DDD) are detected at various concentrations in different locations of Bangladesh. Chowdhury et al. (2013) reported DDT in five several districts in Bangladesh ranging from 0.133 to $8.29 \mu \mathrm{g} / \mathrm{l}$. Matin et al. (1998) detected $19.6 \mu \mathrm{g} / \mathrm{l}$ of DDT in Begumganj, Bangladesh. In an average $0.016 \mu \mathrm{g} / \mathrm{l}$ of DDT was reported in Lake Parishan, Iran (Kafilzadeh et al. 2012). Water sample of Lake Parishan was also contaminated with $0.055 \mu \mathrm{g} / \mathrm{l}$ of DDE (Kafilzadeh et al. 2012).

The present study has revealed that out of 40 water samples none of the water sample from Saturia Upazila was contaminated with pesticides although a trace amount of carbaryl was identified but was below the detection limit. It is also found that, organophosphorus pesticides are being used excessively in Nagarpur Upazila. Lacorte et al. (1995) observed a total of ten organophosphates including malathion, diazinon and some other pesticides which disappeared within 2 weeks. Since, organophosphorus pesticides are degraded very quickly and the samples have been collected randomly, the concentration of organophosphorus pesticides (prior to the collection) may be more than the detected value. The presence of these suspected pesticide residues are an alarming result for the people living in this area. With the increasing population along with increasing demand of food, the uses of pesticides have been increased a lot in the third world countries like Bangladesh. The prolonged consumption of these pesticides through food can be stored in the lipid of human body and may cause severe health hazards.

To reduce the increasing trends of pesticide use and, therefore, the increasing health effect, integrated pest management (IPM) can be a good solution to it. It is the process in which the pest population is suppressed below the level that causes economic injury using all suitable techniques and methods. A panel of experts from the Food and Agriculture Organization (FAO) set the concept of IPM in action in 1968 (Rajinder and Ashok 2009). IPM is the main strategy recommended for pest management under Agenda 21 of the United Nations Conference on Environment and Development (UNCED 1992). The concept of IPM consisted mainly of the use of insecticides in a manner that was compatible with biological control of insect pests but the focus of IPM began to shift to non-pesticidal strategy in the 1980s including expanded use of cultural control, introduction of resistant varieties and biological control (Norris et al. 2003). Implementation of IPM strategies saved USA agriculture from $\$ 500$ million per year due to reductions in pesticide use (Rajotte et al. 1987). Norway started a pesticide reduction plan in 1988 which employed a levied banded tax system based on toxicity at the rate of $\$ 3.8$ per hectare that resulted in a 54\% reduction of pesticide use (PAN, Europe 2004). So, it is a great opportunity for the agro-based countries such as Bangladesh to reduce the possible health hazards as well as costs due to pesticide use applying the IPM strategy.

Acknowledgements Special thanks to the Director of the Institute of Food and Radiation Biology (IFRB) to give the permission for conducting the study.

Open Access This article is distributed under the terms of the Creative Commons Attribution 4.0 International License (http://creativecomm ons.org/licenses/by/4.0/), which permits unrestricted use, distribution, and reproduction in any medium, provided you give appropriate credit to the original author(s) and the source, provide a link to the Creative Commons license, and indicate if changes were made.

\section{References}

Ara AG, Haque W, Hasanuzzaman M (2014) Detection of organochlorine and organophosphorus pesticides residues in water samples of Taragong Thana in Rangpur district in Bangladesh. Res J Environ Earth Sci 6(2):85-89

Bagchi S, Azad AK, Chowdhury MAZ, Uddin MA, Al-Reza SM, Rahman MA (2009) Quantitative analysis of pesticide residues in some pond water samples of Bangladesh. Asian J Water Environ Pollut 6(4):27-30

BBS (Bangladesh Bureau of Statistics) (2013) Statistical yearbook of Bangladesh 2012. Bangladesh bureau of statistics, statistics and informatics division (SID). Ministry of planning, Government of the People's Republic of Bangladesh, Dhaka, 32nd edn. http:// www.bbs.gov.bd

Bhattacharjee S, Fakhruddin ANM, Chowdhury MAZ, Rahman MA, Alam MK (2012) Monitoring of selected pesticides residue levels in water samples of cultivated lands and removal of cypermethrin and chlorpyrifos residues from water using rice bran. Bull Environ Contam Toxicol 89(2):348-353

BIS (Bureau of Indian Standards) (2009) Draft Indian standard, drinking water-specification. Second revision of IS 10500. Manak Bhawan, New Delhi

Braun HE, Frank R (1980) Organochlorine and organophosphorus insecticides: their use in eleven agricultural watersheds and their loss to stream waters in southern Ontario, Canada, 1975-1977. Sci Total Environ 15:169

Brigham ME (1994) Pesticides detected in surface waters and fish of the Red River of the North Drainage Basin. In: North Dakota water quality symposium proceedings, 30-31 March 1994. North Dakota State University extension service, Fargo, pp 256-269

Chowdhury MTI, Razzaque MA, Khan MSI (2011) Chlorinated pesticide residue status in tomato, potato and carrot. J Exp Sci 2(1):1-5

Chowdhury MAZ, Banik S, Uddin B, Moniruzzaman M, Karim N, Gan SH (2012a) Organophosphorus and carbamate pesticide residues detected in water samples collected from paddy and vegetable fields of the Savar and Dhamrai Upazilas in Bangladesh. Int J Environ Res Public Health 9:3318-3329. https://doi.org/10.3390/ijerph9093318

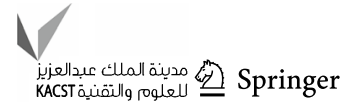


Chowdhury MAZ, Jahan SA, Islam MN, Moniruzzaman M, Alam MK et al (2012b) Occurrence of organophosphorus and carbamate pesticide residues in surface water samples from the Rangpur district of Bangladesh. Bull Environ Contam Toxicol 89:202-207. https:// doi.org/10.1007/s00128-012-0641-8

Chowdhury MAZ, Islam MN, Moniruzzaman M, Gan SH, Alam MK (2013) Organochlorine insecticide residues are found in surface, irrigated water samples from several districts in Bangladesh. Bull Environ Contam Toxicol 90:149-154. https://doi.org/10.1007/ s00128-012-0897-z

DoE (Department of Environment) 2007 Bangladesh National Implementation Plan (NIP) for management of persistent organic pollutants (POPs). Department of Environment (DoE), Ministry of Environment and Forests (MoEF), Government of the People's Republic of Bangladesh

ESDO (Environment and Social Development Organization) (2005) Country situation report on persistent organic pollutants in Bangladesh. In: International POPs elimination project, fostering active and efficient civil society participation in preparation for implementation of the Stockholm convention, Bangladesh

EU (European Union) (1998) EU Council Directive, the quality of water intended for human consumption. Official Journal of the European Commission, 98/83/EC, No. L 330, pp 32-54

Frank R, Logan L (1988) Pesticide and industrial chemical residues at the mouth of the grand, Saugeen and Thames rivers, Ontario, Canada, 1981-85. Arch Environ Contam Toxicol 17:741

GoB (Government of the People's Republic of Bangladesh), MoEF (Ministry of Environment and Forests) (2005) Pesticide inventory of Bangladesh 2005. Field data collection and preparation of inventories on use/stock/production/sources of POPs pesticide in Bangladesh, MoEF

Hancock DB, Martin ER, Mayhew GM, Stajich JM, Jewett R, Stacy MA, Scott WK et al (2008) Pesticide exposure and risk of Parkinson's disease: a family-based case-control study. BMC Neurol 8(1):6

Hasanuzzaman M, Rahman MA, Salam MA (2017) Identification and quantification of pesticide residues in water samples of Dhamrai Upazila, Bangladesh. Appl Water Sci 7:2681-2688. https://doi. org/10.1007/s13201-016-0485-1

Health Canada (2014) Guidelines for Canadian drinking water qualitysummary table. Water and air quality bureau, healthy environments and consumer safety branch, Health Canada, Ottawa

Hossain MS, Chowdhury MAZ, Pramanik MK, Rahman MA, Fakhruddin ANM, Alam MK (2014) Determination of selected pesticides in water samples adjacent to agricultural fields and removal of organophosphorus insecticide chlorpyrifos using soil bacterial isolates. Appl Water Sci 5:171-179. https://doi.org/10.1007/s132 01-014-0178-6

Kafilzadeh F, Shiva AH, Malekpour R, Azad HN (2012) Determination of organochlorine pesticide residues in water, sediments and fish from lake Parishan, Iran. World J Fish Mar Sci 4(2):150-154. http s://doi.org/10.5829/idosi.wjfms.2012.04.02.56399

Lacorte S, Lartiges SB, Garrigues P, Barcelo D (1995) Degradation of organophosphorus pesticides and their transformation products in estuarine waters. Environ Sci Technol 29(2):431-438. https://doi. org/10.1021/es00002a020

Lee W, Blair A, Hoppin J, Lubin J, Rusiecki J, Sandler D, Dosemeci M, Ala- vanja M (2004) Cancer incidence among pesticide applicators exposed to chlorpyrifos in the agricultural health study. J Natl Cancer Inst 96(23):1781-1789

Matin MA, Malek MA, Amin MR, Rahman S, Khatoon J, Rahaman M, Aminuddin M, Mian AJ (1998) Organochlorine insecticide residues in surface and underground water from different regions of Bangladesh. Agric Ecosyst Environ 69:11-15

MoF (Ministry of Finance) (2015) Bangladesh economic review (BER)/ Bangladesh orthonoitik somikkha (in Bengali) 2015, Economic Adviser's Wing, Finance Division, Ministry of Finance, Government of the People's Republic of Bangladesh. http://www.mof.gov.bd
NHMRC (National Health and Medical Research Council), NRMMC (National Resource Management Ministerial Council) (2011) Australian drinking water guidelines paper 6, National Water Quality Management Strategy. Commonwealth of Australia, Canberra. http://www.nhmrc.gov.au

Norris RF, Caswell-Chen EP, Kogan M (2003) Concept in integrated pest management. Prentice-Hall of India Private Ltd, New Delhi

Pahwa P, Karunanayake CP, Dosman JA, Spinelli JJ, McLaughlin JR (2011) Soft-tissue sarcoma and pesticides exposure in men: results of a Canadian case-control study. J Occup Environ Med 53(11):1279-1286

PAN, Europe (2004) Pesticide use reduction is working: an assessment of national reduction strategies in Denmark, Sweden, the Netherlands and Norway. PAN Europe, London

Pimentel D (1997) Techniques for reducing pesticide use: environmental and economic benefits. Wiley, Chichester

Pimentel D (2009a) Pesticides and pest control. In: Peshin R, Dhawan AK (eds) Integrated pest management: innovation-development process, vol 1. Springer, The Netherlands, pp 83-87

Pimentel D (2009b) Environmental and economic costs of the application of pesticides primarily in the United States. In: Peshin $\mathrm{R}$, Dhawan AK (eds) Integrated pest management: innovationdevelopment process, vol 1. Springer, The Netherlands, pp 88-111

Rahman MM (2000) Pesticides: their uses and problems in context of Bangladesh. In: Proceedings of the national workshop on conventional and nuclear technique for pesticide residues studies in food and environment at IFRB, Savar, pp 1-25

Rahman MM (2004) Uses of persistent organic pollutants (POPs) in Bangladesh. In: Paper presented at the inception workshop of the project Bangladesh: preparation of POPs national implementation plan under Stockholm convention (POP NIP), Department of Environment, held at Hotel Sonargaon, Bangladesh

Rajinder P, Ashok KD (2009) Innovation-development process. Integr Pest Manag (Springer Netherlands) 1:1-62. https://doi. org/10.1007/978-1-4020-8992-3

Rajotte EG, Norton GW, Kazmierczak RF, Lambur RF, Allen WA (1987) The national evaluation of extension's integrated pest management (IPM) programs. Virginia Polytechnic and State University, Blacksburg

Recio R, Robbins WA, Borja-Aburto V, Moran-Martinez J, Froines JR, Hernandez RM, Cebrian ME (2001) Organophosphorus pesticide exposure increases the frequency of sperm sex null aneuploidy. Environ Health Perspect 109(12):1237

Uddin MA, Saha M, Chowdhury MAZ, Rahman MA (2013) Pesticide residues in some selected pond water samples of Meherpur region of Bangladesh. J Asiat Soc Bangladesh Sci 39(1):77-82

UNCED (United Nations Conference on Environment and Development) (1992) Promoting sustainable agriculture and rural development. Agenda 21, chap 14. In: United Nations conference on environment and development, Switzerland

Van Wijngaarden RPA, Brock TCM, Van den Brink PJ (2005) Threshold levels for effects of insecticides in freshwater ecosystems: a review. Ecotoxicology 14(3):355-380

WHO (2008) Guidelines for drinking-water quality, 3rd edn, incorporating 1 st and 2 nd addenda. World Health Organization, Geneva, vol 1, pp 296-460. http://www.who.int/water_sanitation_health/ dwq/gdwq3rev/en/. Accessed 9 July 2015

Xu X, Dailey A, Talbott E, Ilacqua V, Kearney G, Asal N (2010) Associations of serum concentrations of organochlorine pesticides with breast cancer and prostate cancer in US adults. Environ Health Perspect 118(1):60-66

Publisher's Note Springer Nature remains neutral with regard to jurisdictional claims in published maps and institutional affiliations. 